\title{
Societal Implications of IT in Religion for Developing Countries
}

\author{
Julius Murumba ${ }^{1}$, Erick Odhiambo Omuya ${ }^{2}$ \\ ${ }^{1}$ Department of Management Science and Technology, Technical University of Kenya, Nairobi, Kenya \\ ${ }^{2}$ Department of Computing and IT, Machakos University, Machakos, Kenya
}

Email address:

j.murumba@gmail.com (J. Murumba),omuya2005@gmail.com (E. O. Omuya)

To cite this article:

Julius Murumba, Erick Odhiambo Omuya. Societal Implications of IT in Religion for Developing Countries. Science Journal of Education . Vol. 5, No. 4, 2017, pp. 144-149. doi: 10.11648/j.sjedu.20170504.13

Received: March 8, 2017; Accepted: April 12, 2017; Published: May 25, 2017

\begin{abstract}
Information Technology has penetrated nearly all aspects of our daily lives such that relationships associated with individuals and organizations are digitally enabled and mediated. Advances in IT have led to changes in the way religious worship has traditionally been done, ushering in a new age of worship that is augmented by or anchored on a digital platform. The paper aimed at investigating societal implications of IT use in religion and to better understand the ways in which IT affects modernization of religion in developing countries. The objectives of the paper were to establish the types of IT applications being used in religion, the co-existence of IT and religious tradition and how use of IT affects the future of religion. The study was conducted through a desk search. The paper concludes that religion and technology have had some form of inter dependence on one another, and therefore for modernization of religion IT will increasingly play an important role. Religion must adopt ways to utilize IT positively while shunning negative aspects that IT can be used for in religion such as propagation of fundamentalism and extremism through IT.
\end{abstract}

Keywords: Information Technology, Religion, Co-Existence

\section{Introduction}

Information Technologies have become widespread and have penetrated deeply into societies in developing countries. These technologies have been widely adopted and have significantly influenced the lifestyles of people in these countries, including religious people. Information technology at the basic level facilitates the recording, communicating, synthesizing and organization of information. Information Technology has become a dynamic and extremely powerful means of collecting, processing, storing, presenting and sharing information in the developing countries. The processed information is usually presented on digital devices, and also to a large extent presented on public infrastructures such as the internet and the World Wide Web. Information Technology refers to the technologies used for the development, use and maintenance of computer systems comprising hardware, software and networks for the collection, processing and distribution of data [1]. The term Information Technology describes physical computer hardware such as servers, desktop computers, including storage devices, computer networks, the internet, business phones and all software systems such as operating systems, application software's and databases [2]. Religion is viewed as a defining characteristic of human societies that are independently created across the world and have an influence on the world's cultures. Uyehara says religion was created to explain phenomenon that confounds humans and to provide spiritual stability for humans [8]. The spiritual health of humans comprises the health of mind, self-acceptance, living peaceably with self, adapting positively oneself to their circumstances, spiritual well-being, individual's effective coping behavior in to stress, a low disposition of depression, and receiving pure religious belief [9]. Definitions of religion vary, and nearly all have a common characteristic of focusing on the communal aspect of religious practice, and they all emphasize on belief, faith, or the supernatural nature of religion [6] argues that religion is an attitude that consists of admitting the existence of a domain of reality that is sacred, supernatural, superior to visible reality, and on which this visible reality depends [10]. This supernatural domain, 
referred to as the sphere of the divine, has been understood in many ways by different cultures and at different times. For example it has been at times articulated into a variety of gods while at different times it has been articulated to mean a unique God. The nature of religion has also been conceived differently, sometimes as totally distinct and separated from the material world in which humans live or transcendence, or conceived as intimately permeating the material world or immanence.

\section{Methodology}

The paper is based on desk research with various sources of literature being reviewed, including research papers in journals and conference proceedings, online journals and reports. The literature search was conducted between the months of September and December 2016.

\section{Importance of IT in Religion}

Information Technology has had an effect on religious practices and ethics in many ways such as propagation of extremist views, brain washing and propagation of hate speech through emerging Information technologies such as the internet and the social media [3]. Technology is understood as practical implementation of intelligence [4], and is therefore a matter of knowing how to express values. [5] Opines that technology in whatever form somehow relates to religion, positively, negatively, or neutrally, since religion is also supremely a matter of values. Information Technology enhances religious practices by facilitating the creation and expansion of religious communities [6]. According to [5], religion has to embrace technology or die, and that the two most common areas that Information Technologies are used in religion are in training for clergy and for religious institutions making their information available. An example is in Christianity in which Information Technology has given it (Christianity) medium through which a world-wide audience can be reached. Christianity has been one of the first religions to adopt and profit from technologies. Ferguson's work indicates that historically there have been advances for Christianity when there were advances in technology [5]. The Pax Romana technology for instance existed at the time of Christ, and played a significant role in the spread of the gospel [7].

On the African continent [11] observes that there is growing scholarship in the field of Information Technologies, religion and culture, and his scholarly work focused on investigating the growth of the new forms of media and their uptake by religious groups. In relation to this scholarly work, there is emergence of new practices where the use of the emerging information and communication technologies by the Catholic Church and the Pentecostal churches is enabling their social involvement in the societal affairs of many countries. According to [12] the estimates of religious populations in Africa indicate that $45 \%$ of Africa's population is Christian, while Muslims are $40.6 \%$, and that
sub-Saharan Africa is predominantly Christian while the north and west are predominantly Muslim. Other forms of minority religions found on the continent include Judaism, Hinduism and Traditional Religion [12].

\section{Types of IT in Religion}

The work of [6] shows that historically religion has enthusiastically adopted and promoted new technologies. For Information Technology, its uses and applications in a religious context are many ranging from the integral and important to the absurd [6]. Personal computers are often used for sermon preparation, personal religious study, while network have been instrumental in communications, and churches have allowed their pastors make use of these technologies [13]. On the flip side an example of Finnish company which in 2004 shut down a service that promised to answer people's prayers with a text message from Jesus. In the same connection, an electronic application called Sun Dial, for instance, can be loaded on a mobile phone to help Muslims remember to pray five times a day [14]. It also seems there are now thousands of apps which allow Christian parishioners to access Bible quotes.

Many churches have also created websites to serve current members and also reach out to new audiences. A website is useful in providing religious institutions with online presence and serves like advertisement of the institution on the internet where anything about the religious institution can be known [13]. Preachers can also use the websites advantage and provide visual sermons online, beaming some aspects of their teachings and preaching topics, text, sub points, other scriptures can be shared through the website. Other forms of Information Technologies that are useful in promoting and delivering religious messages, particularly in churches, are the television screens used to project hymn lyrics or provide audience members with a better view during religious services and electronic amplification equipment used in projecting voices of speaker's voice to large audience's. Reverend Fulton J. Sheen (Time Magazine) observed that in the early 1950s the Roman Catholic Church used the television as a medium to promote their religious messages through sponsoring weekly sermons. Today, majority of pastors in many churches are using different forms of Information Technologies in the areas of sermon preparation, teaching during service and worship. The emergence of the computer and related Information Technologies such as internet and social media have led to congregations using these technologies to promote and enhance traditional worship, fellowship, pastoral care, education, missionary work and community outreach, and communications. [13] citing [15] adds that the benefits of technology make it befitting for religion, especially Information technology which has played a significant role in the spread of Christianity throughout history. Christians for instance have used Information Technology to have Hebrew or Greek words with their explanations to be displayed on a projector through a computer [13], therefore helping worshippers to 
follow, see and internalize the message more. [16] in their work, indicate that religious organizations quite often use Information Technology for conducting their routine or daily business; for example use of a Information Systems for records management, communication, e-commerce and accounting. Thus, some monasteries run internet shops selling icons, books and CD-ROMs, and occasionally usage of the Internet by monks to shop for items they need and for Communication usage of the email and VoIP. [17] as cited by [13] observes that religious organizations are using computer technology primarily in areas of administration and finance, communications, learning and multimedia presentation for worship and education. Use of technology to record Islamic sermons has in recent years become a popular technique for the cultivation of Islamic virtues and are instrumental in the creation of the modes of public sociability these virtues uphold [6]. Using this strategy, sermons of Islamic preachers, popularly known as khutaba are digitally recorded for playback to different audiences in public spaces and have today become a ubiquitous part of the contemporary social landscape in many countries where Muslim populations are significant.

\section{Ways Information Technologies Are Used in Religion}

Historically religion has always depended on technology and in recent years on Information Technology. [7] States that Blaise Pascal, Isaac Newton, and Samuel Morse were scientists who held Christianity and the Bible in the highest regard, and were motivated by the confidence in the rationality behind the universe and the goodness of the material world, implying that these scientists used technology for the good of their religion. For any religion, its longevity is dependent on getting new followers, and for that to happen, the beliefs, rituals and sacred texts of that religion need to be spread and passed down generations [18], and books have historically played a central part to this process. The advancements in Information Technologies, and emergence of newer technologies, has led to situation where these technologies are strongly augmenting books through the internet, world wide web, social media and various forms of multi-media. According to [18], Buddhists have always been on frontline in using the new and emerging technologies. In Japan and in China, Buddhists were among the first religious people to adopt wood block printing on a large scale in order to produce and disseminate their sacred texts on massive scale, which was a huge innovation in a predominantly oral world. Today Buddhists are using technologies such as the Web and podcasts to their advantage more than many other religions. The Zen community in Canada for example is on record for using a service called e-sangha, which provides Buddhists from different parts of world a platform to interact, and to take part in the activities of their religious community online even when they are physically distant. This is of course made possible by a virtual presence in the form of a website which provides a medium for new members to Zen, to take online orientation courses, access podcasts with regular lectures and join discussions [18].

For the Church, many leaders including Pope Benedict XVI have articulated the need to use new technologies to express the word of God to all people of all generations. This has also been articulated in the National Directory for Catechesis which states that, using the media correctly and competently can lead to a genuine enculturation of the gospel [13]. [8] Uyehara cites an interview of [5], a PhD holder in theology and church history with TechNewsWorld to explain that religion has helped to create more efficient forms of communication. A case in point is where Christians in the 16th century replaced the scroll with books because they were more mobile, efficient, and durable. This mobility helped to large extent to reproduce religious texts on a large scale, and changed the fundamental structure of the way religious ideas diffused. Through Information Technology, religion has found a medium to reach a world-wide audience. This underscores the point that historically there have been significant advances for Christianity whenever there have been advances in technology. [7] Work demonstrates that the Christians have always been among the first religious communities to adopt or profit from technologies. Historians have also shown that American Evangelical Protestants adopted communications technologies such as the printing press and telegraph early and enthusiastically because they saw in those systems opportunities to grow their faith by spreading the gospel more broadly [6]. In education, computers, networks and telecommunications have helped not only to increase the efficiency of the religious education, but also make it more understandable and interesting for modern man, especially the youth. After all, the information processing and communication have become today an integral part of any educational process, and is important as any form of teaching or learning [19].

Although, there are many ways in which Information Technology enhances religious practices such as through expansion and creation of religious communities, there are instances where Information Technology degrades religious practices, especially when it breaks communal bonds. [6] observes that though this dual natured relationship to religion can be seen in many technologies, the internet social networking is one of the clearest examples of how technology can both support and erode religious techniques. Information Technology has also displaced the traditional culture of Christianity, especially in the way that church work and worship are conducted. [7] States that he had hoped that the massive resources that are being spent in terms of billions on Sunday Schools, day schools, and Vacation Bible Schools would produce a generation that has its values correct. He adds that he also thought that the huge sums spent on television preaching might have changed societies to be more religious, but eventually he was left to admit that the divorce rate remained the same among those who attended church just like those who did not, and that majority of men between the ages of 18 and 34 who visited pornography web 
sites included believers and church goers. Also remaining the same were the ranks of the high-and-mighty, white collar elite who were corrupt, who included Bible-carrying, churchgoing, God-talking. Religious groups use Information Technology in different ways. [6] shows that Social Networking technology for instance has been used in two main ways 1) religious groups creating their own versions of social network sites that are religion-centric and somewhat exclusive, and 2) using the functions of larger social networks such as Facebook to their advantage. Many internet users with religious affiliations are quite often confronted with a variety of social networking opportunities. Christians have a number of websites such as Hisholyspace.com, holypal.com and Xianz. Additionally there is UltimateTube, which is a Christian alternative to YouTube, providing categories of Christian Videos, Music Videos, and End times Videos. UltimateTube.com exhorts its visitors to broadcast God alone. Other faiths too have their options, Muslims have muslimsocial.com, muxlim.com, and Nasseb, Jews have their social network called Schmooze, and the other earth-based religions too they have their social networks such PaganSpace.net for Wiccans and Druids.

\section{Challenges of Information Technology Use to Its Full Potential in Religion}

The religious outlook and practices of people are usually affected by the world they inhabit. While the Internet and information technologies play a vital role in many people's lives today, there exist people who still live in a world defined by the legacy old media of print, television, radio, and film. This in turn results in religious organizations not being able to use the new opportunities presented by the newer technologies to reach out to such people [21]. [22] states that the role of religion in conflicts is caused by positive and negative developments, for example unifying state and religion in some cases and in others the general desecularisation of the world. Militant forms of religious fundamentalism and extremism have caught the world's attention as a threat to peace. Fundamentalism, according to the [1] means the strict maintenance of the ancient or fundamental doctrines of any religion or ideology. Technologies that underpin modernity, including Information Technologies have not been readily accommodated by the cultures of fundamentalist religious communities, therefore limiting their potential [16]. On the other hand [3] in their study gives a clear reflection on people's perception of the negative use of IT in spreading hatred arguments. There have been instances where sect leaders and religious clerics intentionally raise and float conflicting views amongst their followers that become a verdict for them due to their limited knowledge. Religion, being a major cultural determinant and a strong identifier in global and regional geopolitical conflicts can thus be a limitation to the use of Information Technology in religious practices as well as other facets of life. [13] in her study on Nigerian baptist churches found out that among the challenges faced by Baptist pastors in the use of ICT included lack of IT education, and lack of financial resources, and recommended that, IT training and education become a core part of the curriculum during the training of Baptist pastors.

\section{The Future of IT in Religion}

New technologies are impacting virtually every aspect of human life since these technologies are reshaping our basic notions of who we are, and how we are relating with fellow humans [23]. We increasingly finding ourselves immersed in, and surrounded by digital technologies and networks on which we continue to rely on to conduct our way of life, and this includes religious practices. [19] Work indicates that despite an ongoing debate on whether the Internet can be used for the glory of God, many religious people are already using it, maintaining their own web sites, creating blogs, discussing and exchanging views on social networking sites and network conferencing. On the flipside a significant number are cautious thinking about the prospects of an apocalypse that may result from the total control of technology over man through the internet and the web, seemingly as a result of virtualization and dis-deification of man. [18] indicates that the Brotherhood of St. Alexander Nevsky in Nizhni Novgorod has in the past turned to the internet in order to attract youth to the Orthodox Church, and many churches in developing countries are taking cue. For Sikhs, there has been a trend towards making sacred texts available online, and today it might be easier to find these texts online than in printed form. Other traditions such as Hinduism and Islam are religions in which chanting or singing or scriptures and ritual performances take precedence over solitary study, in which case YouTube can be a marvelous resource. There is little doubt that the Internet will transform religion in future generations because one of the ways of having a tradition that continues and expands is its ability to take advantage of technological and scholarly resources that come along [18]. There exist great opportunities for using computers in religion for educational purposes, especially with recent developments in multimedia. Multimedia technologies are being used to integrate text, audio, images, animation and video into in a single multimedia manual. Multimedia presentations are now being widely used in religion for worship and education. Multimedia is already being used to develop special educational programs for Orthodox schools [19]. The World Wide Web is the most widely used multimedia. The importance of the web in everyday life manifests itself in applications ranging from learning, shopping, banking to socializing, a trend that means that religious institutions and organizations must migrate their churches and temples to virtual real estate because that is where the people are, and also to stay relevant [24]. Today, religious leaders have websites, blogs and Twitter feeds. In addition many faiths have email prayer lines, online confessionals, social networks and applications, and therefore indicates that being web- 
savvy is a necessary skill for religious leaders in general.

Information Technology has also had the potential of destabilizing religion. Take the Church for example, what has traditionally been behind closed doors in ecclesiastical councils is in many instances now accessible on the internet, leading to challenges on the control that leaders once had over doctrine and on their followers. The age of reformation was ushered in by the printing press in the 16th century, and it allowed people to access religious texts for themselves and distribute their interpretations widely. In the same vein, the internet and the web are helping in proliferation of different interpretations and articulations of religions and we have witnessed the emergence of new communities and faiths, in some cases extremism. According to [24] the emergence of the web has led to a situation where individuals have autonomy and a wide range of choices to help them decide where to access a religious resource. This has contributed to emergence of extremism, and is some cases emergence of ideals and endeavor's for fundamentalism and extremism in certain regions of the developing world. [3] posits that positive use of Information Technology in religion can promote harmony and help portray a better image of religion, in for instance Islam which has been in the past portrayed negatively due to violence based activities that have been conducted by militants in the name of Islam. There have also been instances where churches have had to ask congregations to turn off their phones when services begin to avoid distractions posed to congregants by technology during sermon, for example wats app and other social networking. [24] States that there exists a religious apathy among the young and this poses a serious challenge for religious leaders looking to grow their congregations. This is because many of them lack formal religious upbringing resulting in younger worshippers expecting any religious event to embrace technology use. Device multitasking has become a pervasive part of their life so much so that quiet, hard cover book based religious ceremonies seem awkward and therefore not compelling.

Information Technology may represent the end of traditional religious worship, and the beginning of a new age of worship, one which no one can predict or control [25]. Without new young followers, the future for organized religions could be bleak, and for these young followers religion is likely to be appealing to them if it embraces Information Technology. Religious leaders also conduct services via technology to a geographically wide spread audience leading to a significant differences in how worshippers experience the religious worship. According to [25], religion is very much an emotional event and Information Technology can be unfulfilling in that aspect. Gathering around Information Technology in smaller groups may provide an answer to this emotional aspect. The challenge of relying on Information Technology, is how to mobilize through Information Technology and still achieve all the religious personal support and socialization benefits that are realized from real life interaction that emanate from attending a place of worship. In this regard, a virtual congregation may not be a realistic way to gather people and practice religion. [25] Observes further that it is difficult for the younger generations (generation $\mathrm{Y}$ ) to embrace religion without the real life experience where they are using IT and smart devices in all aspects of their lives, which creates for them the feeling of being at peace with oneself. In such cases, worshippers who cannot find their way to their house of worship for services can pray online with their fellow believers via the latest technology. Questions still remain about how powerful that can be but it has been deemed as having been relatively effective through Television, although in many of such cases those are already followers seeking religious celebrities, not new believers.

\section{Conclusion}

This study is a step towards providing information on the types of Information Technologies being used in Religion and how they are being used, and the benefits of using these Information Technologies in religion. The study highlighted the Importance of Information Technologies in religious practices, the types of the Information Technologies being used as well as the challenges likely to be encountered in utilization of these technologies to their full potential. The paper concludes that Information Technologies, in particular emerging technologies such as social networking technologies, wireless technologies, cellular phones and other data processing applications have created new opportunities for social change and religious worship. Information technologies are an important resource which theologians can work with in order to positively affect the context for and of religion. This paper therefore recommends that religious leaders from the popular religions be in the forefront in advocacy of use of Information Technologies positively in religion.

\section{References}

[1] Merriam-Webster Dictionary. (2016). merriam-webster.com. Retrieved December 10, 2016, from https://www.merriamwebster.com/dictionary/information $\% 20$ technology

[2] Webopedia. (2016). Retrieved October 30, 2016, from http://www.webopedia.com/TERM/I/IT.html

[3] Rehman, B., Sultan, A., \& Zeeshan, M. (2015). Role Of Information Communication Technology In Provoking Religious Extremism. The Explorer Islamabad: Journal of Social Sciences, 1 (5), 145-148.

[4] Encyclopedia of Science and Religion. (2016). Retrieved November 7, 2016, from Encyclopedia.com: http://www.encyclopedia.com/education/encyclopediasalmanacs-transcripts-and-maps/technology-and-religion

[5] Ferguson, T. (2004). Retrieved October 30, 2016, from TechNewsWorld:

http://www.technewsworld.com/story/33078.html

[6] Verschoor-Kirss, A. (2012). The Dynamic Interplay of Religion and Technology in Online Social Networks. Journal of Religion \& Society, 14. 
[7] Sims, D. B. (2005). The Effect of Technology on Christianity: Blessing or Curse? Unpublished.

[8] Uyehara, K. (2006). Religion and Technology. Retrieved November 8, 2016, from Swarthmore College Environmental Studies:

http://fubini.swarthmore.edu/ ENVS2/S2007/kuyehar1/Religi on_essay.html

[9] Cheng, C. M., Liu, Y. Y, \& Ho, R. L. (2006). The Impact of Internet Technology on Spiritual Health of College Students. Proceedings of the 5th WSEAS International Conference on Applied Computer Science (pp. 33-38). Hangzhou, China: International Conference on Applied Computer Science.

[10] Agazzi, E. (2011). Science and Religion. History And Philosophy Of Science And Technology, 1, 3-4.

[11] Ihejirika, W. C. (2008). In-Line Religion: Innovative Pastoral Applications Of The New Information And Communication Technologies (Nicts) By The Catholic Church In Nigeria. Politics And Religion, 79-98.

[12] Manala, M. J. (2014). The impact of Christianity on subSaharan Africa. Pretoria, South Africa: University of South Africa.

[13] Ossai-Ugbah, N. B. (2011). The use of information and communication technologies in Nigerian Baptist churches. International Journal of Science and Technology Education Research, 2 (3), 49 - 57.

[14] Wyche, S. P., Hayes, G. R., Harvel, L. D., \& Grinter, R. E. (2011). Technology in Spiritual Formation: An Exploratory Study of Computer Mediated Religious Communications. Computer Supported Cooperative Work.

[15] Pautler A (2010). Why We Use Technology. http://newcitycatholicchurch.com/blog

[16] Tanasyuk, P., \& Avgerou, C. (2009). ICT and religious tradition: the case of Mount Athos. IFIP WG9.4 Conference. Dubai: London School of Economics Research Online.
[17] Armstrong, N. S., Spiegel, A., \& Wimmer, J. (2001). Information technology in congregations. Christian century, $7-14$.

[18] Gorichanaz, T. (2014). Religion and information technology. Retrieved November 8, 2016, from scratchtap: http://scratchtap.com/religion-and-information-technology/

[19] Starichenkov, A. V. (1996). Using information technologies in religious education. Retrieved November 8, 2016, from Round Table "Education for change and diaconia": http://www.rondtb.msk.ru/info/en/technologies_en.htm

[20] Soukup, P. A., Buckley, F. J., \& Robinson, D. C. (2001). The Influence Of Information Technologies On Theology. Theological Studies.

[21] Reychler, L. (1997). RELIGION AND CONFLICT. International Journal of Peace Studies, 2 (1).

[22] Holmlund, S. (2008). How is technology changing spirituality? Retrieved November 8, 2016, from http://www.patheos.com: http://www.patheos.com/Topics/How-Is-TechnologyChanging-Spirituality

[23] Krotoski, A. (2011). What effect has the internet had on religion?. Retrieved October 30, 2016, from The Guardian: https://www.theguardian.com/technology/2011/apr/17/untangl ing-web-aleks-krotoski-religion

[24] Yates, P. (2014). Technology's effect on religion. Retrieved November 8, 2016, from DevOps.com: https://devops.com/technology-killing-religion-just-know/

[25] Time Magazine 1952 "Bishop Fulton Sheen: The First 'Televangelist."' Time Magazine (April 14). Available online at http://www.time.com/time/magazine/article/0,9171,857161,00 .html. 